\title{
TEKNIK PEMBUATAN SERPIH BILAH DENGAN PENDEKATAN ARKEOLOGI EKSPERIMENTAL
}

\section{The Techniques of Making Blade-Flake with Experimental Archaeological Approach}

\author{
Ansar Rasyid \\ Alumni Jurusan Arkeologi Universitas Hasanuddin \\ J1. Perintis Kemerdekaan, km. 10, Makassar, Indonesia \\ st.keppo@gmail.com
}

Naskah diterima: 07/07/2017; direvisi: 19/10-30/11/2017; disetujui: 30/11/2017

Publikasi ejurnal: 12/12/2017

\begin{abstract}
The theme of the research is the technique of making blades using an experimental archaeological approach. This experimental activity used as a reference to explain the possible ways in which human beings produce artifacts. This research has two problems, how the process of making blades by direct sampling techniques and what forms are generated from the selection of striking platform at random and in one flat plane on the material. The purpose of this study is to find out the possibility of the ways of human life of the past in terms of making stone tools and to know in detail the process of making blades. The methods used include data collection, data processing and data interpretation by analyzing based on the process of making the blades and the resulting shapes. Experimental results by flake artefacts, show human skill in making tools and mental ability to think and prepare the operational sequence. The operational sequences in this experiment can illustrate the sequence of processes of making the actual type of stone artefacts.
\end{abstract}

Keyword: Experiment, duplication, blades-flake, mental ability.

\begin{abstract}
Abstrak
Penelitian yang dilakukan bertemakan, teknik pembuatan serpih bilah dengan menggunakan pendekatan arkeologi eksperimental. Aktivitas eksperimen inilah yang dijadikan acuan untuk menjelaskan kemungkinan cara yang ditempuh manusia dalam hal memproduksi artefak. Penelitian ini memiliki dua permasalahan meliputi, bagaimana proses pembuatan serpih bilah dengan teknik penyerpihan langsung dan bentuk apa sajakah yang dihasilkan dari pemilihan dataran pukul secara acak dan di satu bidang datar pada material. Tujuan penelitian ini untuk mengetahui kemungkinan cara-cara hidup manusia masa lampau dalam hal membuat alat batu serta mengetahui secara rinci proses pembuatan serpih bilah. Metode yang digunakan meliputi pengumpulan data, pengolahan data dan interpretasi data dengan menganalisis berdasarkan pada proses pembuatan serpih bilah dan bentuk yang dihasilkan. Hasil eksperimen berupa artefak serpih-bilah, memperlihatkan keahlian manusia membuat alat serta kemampuan mental memikirkan dan mempersiapkan rangkaian operasionalnya. Rangkaian operasional dalam eksperimen ini dapat memberi gambaran tentang rangkaian proses pembuatan jenis artefak batu yang sebenarnya.
\end{abstract}

Kata Kunci: Eksperimen, duplikat, serpih-bilah, kemampuan mental.

\section{PENDAHULUAN}

Alat batu yang sering ditemukan di situs-situs prasejarah memiliki bentuk dan jenis yang beraneka ragam, salah satunya dikenal dengan istilah alat batu kerakal ${ }^{1}$. Alat batu kerakal dibentuk dari dua atau tiga tatalan yang dipukul sampai ujungnya lepas. Sisi tajam atau lancipan digunakan sebagai tajaman dan sisi lainnya berfungsi sebagai media genggaman atau pegangan yang tidak menimbulkan rasa sakit pada saat digunakan. (Howell, 1977: 102-103).

\footnotetext{
${ }^{1}$ Sebagian besar para ahli menyebutnya dengan istilah alat inti atau alat masif.
} 
Perkembangan selajutnya, yaitu tradisi serpih (flakes) menghasilkan artefak yang berbentuk sederhana dengan kerucut pukul yang jelas. Bahan baku batuan yang sering digunakan diantaranya, beberapa batuan tufa dan kapur kersikan serta batuan endap (Soejono, 1993: 110).

Teknik pembuatan serpih-bilah merupakan lanjutan dari teknik yang dipakai pada alat batu inti yaitu penyerpihan (Soejono, 1993: 193). Alat batu inti dibuat dari pemangkasan langsung gumpalan batu kemudian digunakan sebagai alat, sedangkan alat-alat serpih dilepas dari gumpal batu melalui pemangkasan khusus secara langsung (direct) dengan batu martil atau secara tidak langsung (indirect) dengan menggunakan pahat-tulang atau tandukyang dipukulkan pada gumpal dengan martil (Soejono, 1993: 25). Perkembangan pembuatan artefak terlihat dari artefak yang dihasilkan semakin lama semakin halus dengan teknik pembuatan yang lebih kompleks.

Teknik pembuatan artefak batu sudah menjadi bahan pembicaraan para ahli di Eropa dan Amerika sejak akhir abad IX sampai pertengahan abad XX, walaupun kajian tersebut masih menjadi simpangan kecil (belum populer) dalam Arkeologi (Whitteker, 2004: 37). Eksperimen pembuatan dilakukan para ahli untuk menerka proses dan teknik pembuatan artefak batu. Selain eksperimen pembuatan, para ahli juga melakukan eksperimen penggunaan artefak batu, hal ini dilakukan untuk mengetahui perkembangan cara penggunaan dan bentuk kerusakannya. Wacana yang dikenal dengan istilah Experimental Archaeology ini pernah dilakukan oleh J. Desmond Clark, Louis Leakey, dan S.A Semenov (Howell, 1977: 103).

Salah satu ahli eksperimen Charlie Shawey, dijuluki modern knapper ${ }^{2}$, memiliki kemampuan membuat point yang

2 Knapper adalah sebutan untuk orang yang mempunyai keterampilan membuat artefak batu (lihat John C paling sempurna dibandingkan knapper lainnya. Selain itu, eksperimen pembuatan artefak batu juga pernah dilakukan dengan teknik yang rumit dan menggunakan peralatan yang modern. John C. Whitteker adalah pengikut Charly Shawey sebagai knapper, juga pernah melakukan eksperimen dan mendapat pengarahan langsung dari Charly, serta masih banyak ahli dan peminat artefak batu yang pernah melakukan eksperimen pembuatan artefak batu (Whitteker, 2004: 34-61).

Dengan demikian dapat disimpulkan bahwa kajian arkeologi eksperimental khususnya eksperimental pembuatan artefak batu telah dilakukan oleh banyak ahli. Teknik dan peralatan yang diperagakan para ahli dalam eksperimen bermacam-macam, mulai dari teknik dan peralatan yang sederhana -menggunakan batu pukul dari batu keras- sampai pada teknik yang rumit dengan menggunakan peralatan yang modern. Kegiatan eksperimen yang dilakukan para ahli mampu menghasilkan berbagai macam artefak batu, dari yang sederhana -artefak batu inti dan serpihsampai artefak yang pengerjaannya detail. Selain eksperimen pembuatan artefak batu, para knapper juga mempraktekkan cara penggunaan artefak batu yang dihasilkan untuk mengetahui bentuk kerusakan pada artefak yang digunakan.

Arkeologi Eksperimental sudah dijadikan salah satu alat analisis penting dalam arkeologi khususnya di Eropa dan Amerika, tetapi di Indonesia kajian ini tidak sepopuler kajian arkeologi tematik lainnya. Kajian tersebut dianggap penting untuk mengetahui lebih dalam tentang kajian arkeologi eksperimental khususnya eksperimen pembuatan artefak batu, untuk kemudian dijadikan alat analisis atau pendekatan dalam analisis artefak batu.

Analisis arkeologi eksperimental pernah diterapkan di Indonesia oleh Foriester (2007) di situs prsejarah Song

Whitteker. 2004. American Flintknappers. University of Texas Press. USA) 
Keplek, Gunung sewu, Jawa timur ${ }^{3}$. Analisis eksperimen yang dilakukan membantu peneliti menjelaskan cara manusia memproduksi alat batu mulai dari proses perolehan bahan sampai pada proses pembuatan alat batu. Gambaran tersebut diperoleh setelah Foriester melakukan eksperimen secara keseluruhan mulai dari lokasi pengambilan material, proses pengambilan material sampai pada pembuatan artefak batu.

Berdasarkan permasalahan di atas, bahwa eksperimen pembuatan artefak batu tidak cukup dengan mempelajari teori dari para ahli. Proses sebenarnya dapat diketahui dengan cara mempraktekkan langsung proses pembuatan artefak batu. Maka untuk melakukan eksperimen pembuatan artefak batu dengan teknik yang sederhana -teknik penyerpihan langsung (direct percussion) menggunakan batu pukul- dan fokus pada pembuatan serpih-bilah serta menerapkan teknik pemilihan dataran pukul pada satu bidang datar dan pemilihan dataran pukul secara acak pada material.

Penelitian bertujuan untuk mengetahui kemungkinan cara-cara hidup manusia masa lampau dalam hal membuat artefak batu. Secara teknis penelitian ini difokuskan pada rangkaian operasional pembuatan alat batu lebih khusus pada alat serpih-bilah, serta mengetahui secara rinci proses pembuatan serpih-bilah dengan menggunakan teknik penyerpihan langsung (direct percussion) dengan tekanan pada satu sisi material (unipolar).

Penelitian ini diharapkan dapat menambah perbendaharaan data dan memperkaya tema pembahasan serta membuka lebar kesempatan untuk membahas lebih dalam tentang tema arkeologi eksperimental. Sedangkan dari sisi praktis diharapkan kajian ini dapat dijadikan salah satu alternatif oleh pihak terkait dalam

${ }^{3}$ Lihat Hubert Foriester. 2007. Ribuan Gunung, Ribuan Alat Batu. Prasejarah Song Keplek, Gunung Sewu, Jawa hal memperkenalkan objek-objek arkeologi pada manyarakat. Misalnya, perkembangan kajian arkeologi akhir-akhir ini yang diarahkan pada pelestarian sumberdaya budaya. Dengan menggunakan pendekatan eksperimental yang didesain sedemikian rupa, dapat dijadikan media publikasi yang menarik bagi masyarakat -melibatkan langsung masyarakat dalam ekperimen pembuatan alat batu-, sehingga objek-objek arkeologi -khususnya prasejarah- semakin dikenal.

Arkeologi eksperimental dirancang untuk meniru fenomena masa lalu. Prinsip dasar dari arkeologi eksperimental adalah percobaan, pengujian kualitas sebuah situs, struktur, perkakas atau senjata. Semua buatan manusia itu akan terlihat dengan eksperimen arkeologi dari tiga dimensi (Coles, 1979: 33-34). Khusus artefak batu, eksperimen pembuatan bertujuan untuk mendapat gambaran tentang cara-cara manusia memproduksi alat batu.

Metode arkeologi eksperimental sebelumnya telah dilakukan oleh beberapa peneliti. Metode ini dilakukan untuk menjawab permasalahan penelitian yang dihadapi. Francois Bordes seorang guru besar prasejarah dari Universitas Bordeaux, Prancis, mempraktekkan cara membuat alat batu dari batu api. Dengan teknik pemangkasan langsung serta menggunakan percutor $^{4}$ dari batu dan tanduk rusa, dia mampu menghasilkan alat berupa lancipan yang digunakan oleh pemburu zaman batu sebagai mata lembing untuk menikam (Howell, 1977: 118).

Charlie Shawey, sebagian hasil karyanya dikoleksi sendiri dan sebagian lagi dikomersilkan. Selanjutnya Whitteker, seorang arkeolog yang mengikuti jejak Charlie sebagai knapper. Whitteker belajar banyak tentang proses pembuatan artefak batu dari Charlie, dan juga diperkenalkan

Timur. KPG, Institut de Recherche pour le Developpment, Puslit Arkenas. Forum Jakarta Paris.

${ }^{4}$ Percutor adalah alat yang digunakan dalam membuat alat batu atau alat yang digunakan sebai pemukul (hammer). 
dengan para kolektor yang sering bertransaksi dengan Charlie. Buku yang ditulis Whitteker juga mengemukakan alasan para knapper menjalani profesinya sebagai knapper, dari sekedar hobi, serta memanfaatkan hasil karyanya untuk keuntungan pribadi (Whitteker, 2004: 3471).

John Coles, pernah menulis buku berjudul Archaeology by Experiment (1973) dan Experimental Archaeology (1979). Tujuan eksperimen menjadi salah satu pembahasan dalam buku yang diterbitkan oleh Hutchinson University, di London. Selain itu, juga menjelaskan beberapa teknik yang digunakan oleh manusia masa lampau untuk membuat berbagai macam peralatan, termasuk teknik membuat alat batu. Alan K. Outram juga pernah menulis artikel tentang pengantar dan pendekatan dalam arkeologi eksperimental serta tujuan arkeologi eksperimental (Outram, 2008).

Beberapa metode sebagai teknik dasar pemukulan batu untuk membuat alat serpih yang bisa dijadikan acuan dalam eksperimental pembuatan alat batu, diantaranya:

1) dengan menggunakan batu sebagai palu. Si pembuat alat memberi pukulan keras tepat di belakang tepi inti alatnya,

2) dengan menggunakan batu paron, si tukang memukulkan alatnya pada batu yang kukuh, dan dengan demikian mendapatkan serpihan dari permukaan atas,

3) dengan palu dari kayu ataupun tulang sebagai tahap akhir, si tukang berulang kali mengetuk tepi alatnya untuk melepaskan kepingan tipis,

4) dengan alat runcing dari tulang, tanduk rusa atau kayu keras, si tukang mendorong serpihan dari tepi alat dengan menekan maju pada batu yang secara hati-hati digenggam kuat dengan kulit (Howell, 1977: 110-111).

Sedangkan, menurut Citra Andari (1995) dari Jurusan Arkeologi Unversitas Hasanuddin, pernah menulis tema arkeologi ekperimental. Tulisan tersebut dibuat dalam rangka tugas akhirnya sebagai mahasiswa di Jurusan Sejarah dan Arkeologi, Fakultas Sastra, Universitas Hasanuddin. Skripsi tersebut menjelaskan tentang metode yang digunakan untuk membuat lukisan cap tangan yang banyak ditemukan di gua prasejarah Maros-Pangkep. Percobaan dilakukan dengan menggunakan pewarna buatan yang sifatnya sama dengan pewarna aslinya. Percobaan diterapkan dengan teknik penyemprotan pewarna buatan dari berbagai arah pada media kertas yang dilekatkan di dinding. Gambar yang dihasilkan sebisa mungkin mirip dengan lukisan aslinya. Maka tujuan dari eksperiman, yaitu menguji dan mengamati kemungkinan teknik yang digunakan dalam pembuatan lukisan cap tangan.

\section{METODE PENELITIAN}

Tahap awal penelitian dilakukan dengan mengumpulkan literatur yang berhubungan dengan tema penelitian. Literatur yang dibutuhkan untuk penelitian, yaitu referensi yang berkaitan dengan artefak batu khususnya jenis-jenis artefak batu, dan referensi tentang tema arkeologi eksperimental khususnya eksperimen pembuatan artefak batu. Selain itu, referensi tambahan tentang jenis batuan juga dibutuhkan untuk mengetahui segala sesuatu yang berhubungan dengan bahan baku serpih, serta referensi lain yang dianggap penting. Setelah itu, data hasil eksperimen yang terdiri dari material akan diuraikan berdasarkan kelompoknya yaitu serpih dan batu inti, keduanya akan diuraikan pula mengenai ukuran, bentuk dan atributnya. Begitupun dengan batu pukul, akan diuraikan ukuran, bahan, bentuk dan bekas pakai.

Setelah pengelompokan hasil eksperimen, maka akan menganalisis data tersebut berdasarkan proses pembuatan serpih bilah dan bentuk serpih yang dihasilkan. Langkah kerja yang dilakukan yaitu dengan mengamati atribut artefak. 
Berdasarkan jenisnya, atribut dibagi menjadi tiga kategori yang meliputi bentuk, teknologi dan gaya (Anonim, 1999: 39-40).

\section{HASIL DAN PEMBAHASAN}

\section{Profil Wilayah}

Kabupaten Barru terletak di antara koordinat 4 5' 49" -4 47' 35" LS dan 199 35' 00" - 119 49' 16" BT dengan luas wilayah sekitar $1.174,72 \mathrm{~km}^{2}$, berjarak \pm 102 $\mathrm{km}$ ke arah Utara kota Makssar, dengan waktu tempuh \pm 2 jam menggunakan kendaraan bermotor. Kabupaten Barru berbatasan langsung dengan kota Pare-Pare di sebelah Utara, sebelah Timur berbatasan dengan Kabupaten Soppeng dan Kabupaten Bone, sebelah Selatan berbatasan dengan Kabupaten Pangkep dan sebelah Barat berbatasan dengan Selat Makassar.

Secara administrasi lokasi tempat pangambilan material masuk dalam wilayah Dusun Panasae, Kelurahan Lompo Riaja, Kecamatan Tenete Riaja, Kabupaten Barru (berada pada titik koordinat $04^{\circ} 33^{\prime}$ 05,5" LS $119^{\circ} 43^{\prime}$ 55,7” BT). Sedangkan lokasi kedua masuk dalam wilayah Desa Tille, Kecamatan Tenete Riaja, Kabupaten Barru (berada pada titik koordinat 04 33' 29,4'LS $119^{\circ} 43$ ' 31,7” BT). Kedua lokasi ini dipisahkan oleh sungai Ralla - warga sekitar menyebutnya Salo Ralla-. Hulu Sungai Ralla di Desa Wessae -sekitar $1 \mathrm{~km}$ sisi Timur Dusun Panasae-, Kecamatan Tanete Riaja, Kabupaten Barru dan bermuara di Selat Makassar. Sungai Ralla merupakan sungai purba, dimana penelitian geologi yang didasarkan pada analisa fosil planktonic di sungai tersebut menghasilkan umur Eosen Bawah bagian Atas - Eosen Tengah bagian Tengah (Arifin, 2013: 7).

Dusun Panasae berada di sebelah utara Sungai Ralla, berjarak $\pm 4 \mathrm{~km}$ dari ibukota Kecamatan. Lahan produktif Dusun Panasae berada di sekitar lereng gunung sampai ke sisi Sungai Ralla dengan ketinggian $\pm 100 \mathrm{mdpl}$. Lahan tersebut dimanfaatkan sebagai areal persawahan dan ladang untuk tanaman Palawija (padi, jagung, kacang-kacangan, dan umbiumbian). Sebagian lagi dimanfaatkan sebagai lahan tanaman Rumput Gajah untuk pakan ternak. Sekitar lereng terdapat sungai kecil -warga menyebutnya Salo Panasaeyang bermuara di sungai Ralla. Daerah aliran sungai Panasae banyak mengandung material batuan, salah satu di antaranya yaitu batuan chert. Material chert ditemukan tersingkap diantara material sungai yang lain.

Material batuan chert tidak hanya ditemukan di sekitar aliran sungai, tetapi di areal persawahan dan ladang warga juga mengandung material batuan chert. Bentuk material batuan chert yang ditemukan di sungai ini bulat atau bulat lonjong dan terkadang dalam keadaan tidak utuh (pecah) dengan kulit batuan yang tipis. Sedangkan yang ditemukan di sawah dan ladang dominan dalam keadaan utuh dan memiliki kulit batuan yang tebal.

Selain material chert dengan bentuk utuh atau pecah, artefak serpih juga ditemukan di lokasi yang sama. Perkiraan sementara, serpih-serpih yang ditemukan adalah artefak batu berdasarkan identifikasi awal jejak teknologi yang ada pada serpih. Bentuk serpih yang ditemukan berbeda-beda diantaranya, pipih, segi tiga, segi panjang, dan lain-lain. Desa Tille berada di sisi selatan Sungai Ralla. Desa Tille diapit oleh tiga bukit gamping. Morfologi lahan pemukiman cukup datar dan berada pada ketinggian $300 \mathrm{mdpl}$. Lahan yang produktif berada di sekitar lereng sampai di sisi Sungai Ralla. Sebagian besar lahan dimanfaatkan untuk areal persawahan dan ladang yang ditanami tamanan Palawija dan Rumput Gajah.

Material chert di kawasan ini lebih dominan dibandingkan material batuan lain. Material tersebut ditemukan mulai dari pemukiman sampai lahan persawahan dan ladang warga. Material batuan chert dimanfaatkan warga untuk pagar pembatas lahan yang disusun sampai ketinggian kirakira 100-150 cm. Sekitar bukit kars juga 


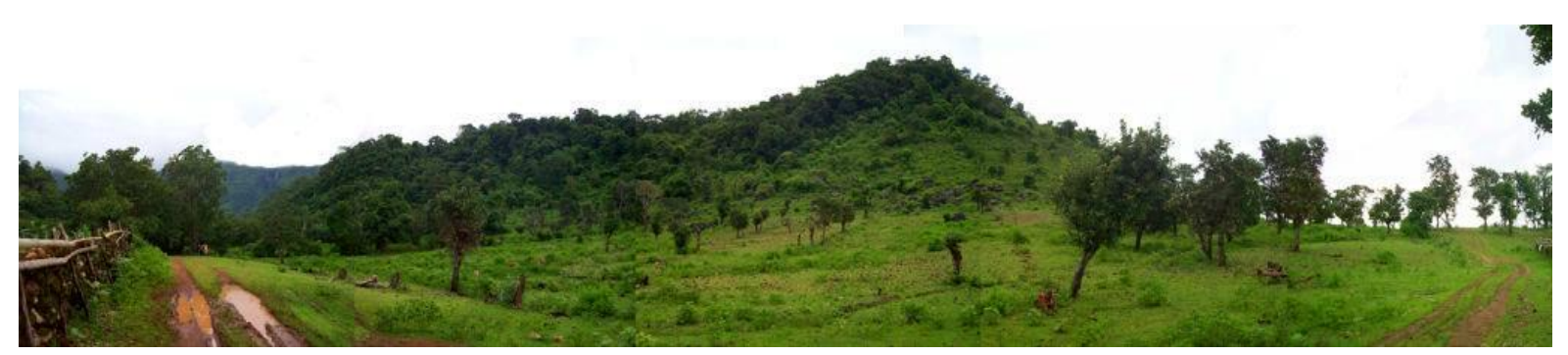

Gambar 1. Bentang alam Desa Tille,

(Sumber: Dokumentasi Ansar Rasyid, Tahun 2011)

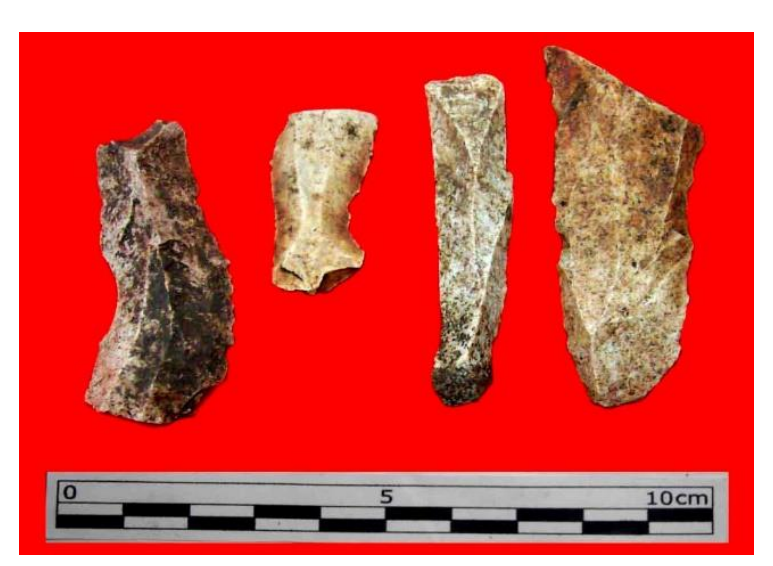

Gambar 2.Temuan serpih di Desa Tille (Sumber: Dokumentasi Ansar Rasyid, Tahun 2011)

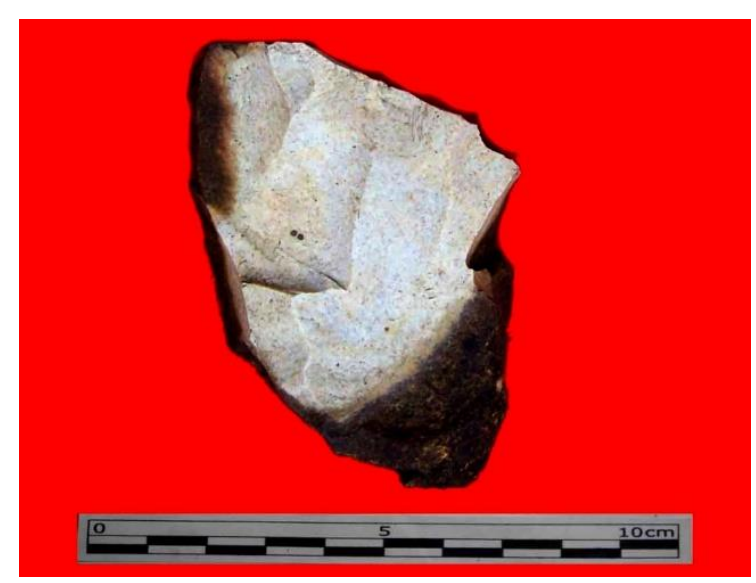

Gambar 3. Temuan batu inti di Desa Tille (Sumber: Dokumentasi Ansar, Rasyid, Tahun 2011)

ditemukan batuan chert yang masih berada pada endapan primer -masih melekat di batuan gamping. Temuan arkeologis berupa artefak batu -serpih dan batu inti- juga ditemukan diantara material chert. Sebagian besar artefak batu yang ditemukan dari bahan dasar batuan chert, dan beberapa diantaranya dari batuan gamping. Lokasi lain tempat ditemukannya budaya serpih di wilayah Kabupaten Barru berada di Desa Wessae yang juga merupakan hulu Sungai Ralla (Idris, 1996; Anonim; 2001; 2003; Utomo, 2003: 70).

\section{Proses Eksperimen}

\section{a. Perolehan Bahan}

Teknik pengambilan material yang diterapkan di lokasi beraneka ragam. Perbedaan teknik ini dikarenakan letak, kondisi dan bentuk material yang ditemukan berbeda-beda. Dibutuhkan beberapa teknik untuk memperoleh setiap material, di antaranya: Pengambilan secara langsung adalah pengambilan bahan material yang telah tersedia secara langsung tanpa persiapan dan pengerjaan khusus. Batuan material yang biasanya berbentuk nodul ini, telah mengalami proses transformasi dari tempat asalnya menuju ke sungai sehingga pecah menjadi beberapa bagian. Dengan demikian, material sudah siap pakai tanpa harus ditambang dari batu induknya atau diperkecil. Pengambilan secara langsung dilakukan pada salah satu material yang ditemukan di sisi Sungai Panasae dan di areal perkebunan warga Tille. Material yang ditemukan dalam kondisi seperti ini diambil secara langsung tanpa perlakuan khusus.

Penambangan adalah pengambilan material yang dilakukan dengan cara menggali, mencungkil, dan memukul batuan material sehingga terlepas dari posisi awalnya. Material yang ditambang dilakukan di pematang sawah warga Panasae, yang posisi awalnya terkubur dalam tanah. Material dengan kondisi seperti 
ini diperoleh dengan menggunakan peralatan berupa sudip atau linggis agar dapat dikeluarkan dari dalam tanah. Lain halnya dengan material yang masih melekat pada batu gamping atau batu induknya, proses pengambilannya dilakukan dengan cara menggunakan alat pukul agar mudah lepas. Alat pukul dibenturkan ke material yang ingin dilepas dari batuan induknya.

Penyerpihan adalah cara yang digunakan untuk memperkecil ukuran material. Material diperkecil untuk mendapatkan kualitas terbaik dari satu material serta memudahkan dalam proses pengangkutan. Material diserpih langsung dengan menggunakan batu pukul keras (batu pukul lebih besar dari penyerpihan biasa). Serpih-serpih yang dihasilkan pada proses ini berukuran besar dan sebagian besar berkorteks. Teknik penyerpihan yang digunakan yaitu teknik penyerpihan langsung dengan tekanan dari dua arah, di antaranya tekanan dari batu pukul dan tekanan dari arah bawah atau dari landasan. Material yang dapat diangkat dengan satu tangan diserpih langsung dengan tekanan dari satu arah saja.

Pembenturan adalah membenturkan material batuan chert ke material chert lain yang lebih besar. Proses ini bertujuan untuk memecah material yang berukuran besar menjadi beberapa bagian yang lebih kecil. Tekanan besar pada material pada saat dibenturkan akan memudahkan material pecah menjadi beberapa bagian, beberapa pecahan akan dijadikan bahan baku pembuatan serpih.

Pelemparan adalah melempar material yang ingin dipecah menggunakan batu pukul. Batu pukul yang digunakan ukurannya lebih besar dari batu pukul untuk penyerpihan. Material batu chert yang ditemukan di lokasi cukup besar, ukuran panjang $50 \mathrm{~cm}$, lebar $45 \mathrm{~cm}$, tebal $15 \mathrm{~cm}$. Material ini dipecahkan dengan cara dilempar menggunakan batu andesit. Material diposisikan miring agar mudah dilempar. Sasaran pelemparan yaitu bagian pinggir (tepi) material. Bagian pinggir material lebih mudah pecah dibandingkan bagian tengah. Material yang sudah terbagi dalam beberapa bagian dipilih untuk bahan baku serpih. Beberapa bagian lain diserpih untuk mendapatkan ukuran yang ideal untuk eksperimen.

\section{b. Eksperimen Material}

Secara umum teknik penyerpihan yang digunakan pada saat penyerpihan adalah penyerpihan langsung menggunakan batu pukul keras. Satu tangan memegang material dan satunya lagi memengang batu pukul. Tangan yang memegang batu pukul adalah tangan yang paling kuat. Tugasnya, selain memberi tekanan pada material dengan batu pukul juga mengontrol ketepatan sasaran pukulan. Batu pukul dipegang dengan cara digenggam. Salah satu sisi dari batu pukul ditonjolkan di antara ibu jari dan jari telunjuk -sisi yang ditonjolkan adalah sisi yang lancip atau lonjong-. Sisi yang menonjol inilah yang akan berbenturan dengan material pada saat penyerpihan.

Posisi jari yang menggenggam material -kelingking, manis, tengah dan telunjuk- tepat berada di sisi luar bidang yang ingin dilepas. Keempat jari tangan ini bertugas menahan serpihan agar tidak terpental jauh pada saat serpihan lepas dari batu inti. Serpih yang terpental

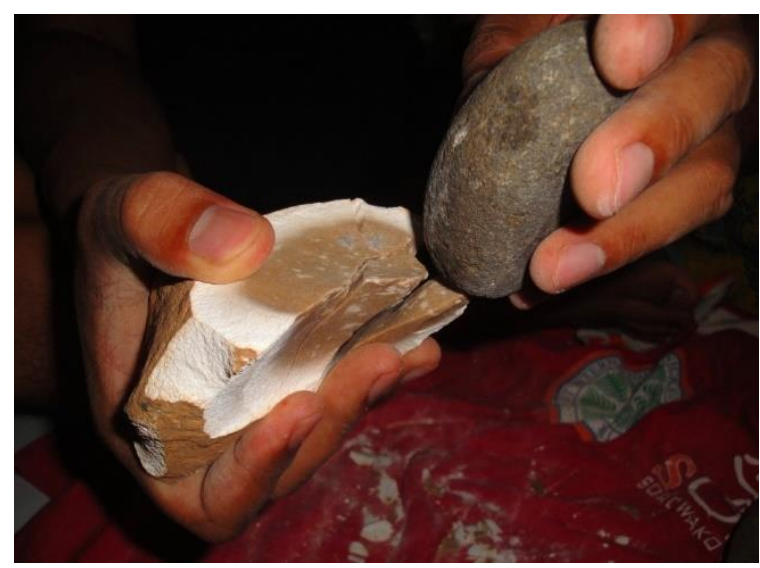

Gambar 4. Cara memegang batu pukul dan batu inti

(Sumber: Dok. Ansar Rasyid, Tahun 2012). 
kemungkinan akan patah atau berpotensi melukai jari tangan yang bertugas menahan serpihan. Sedangkan posisi ibu jari diposisikan berlawanan arah dengan posisi keempat jari yang lain. Ibu jari bertugas menahan material agar tidak terlepas dan menghindari terjadinya getaran yang berlebihan $^{5}$ pada material saat mendapat tekanan dari batu pukul. Pergelangan tangan pada saat menggenggam material sebisa mungkin mendapatkan tumpuan untuk menghindari getaran yang berlebihan sekaligus menguragi beban tangan jika material yang dipegang cukup berat. Bagian tubuh yang tepat dijadikan tumpuan, yaitu paha atau lutut. Pergelangan tangan diletakkan di atas paha atau lutut.

Pada saat penyerpihan, posisi dataran pukul dimiringkan (diagonal) atau diposisikan lurus (horizontal). Sasaran pukulan pada dataran pukul yang diposisikan diagonal adalah di bagian tepi dataran pukul paling bawah. Sasaran pukulan yang tepat adalah titik yang sejajar dengan faset -jika ada faset- yang terbentuk pada penyerpihan sebelumnya dengan kemiringan maksimal $90^{\circ}$. Jarak ujung faset dengan titik pukul, menentukan tebal atau tipisnya serpih yang dihasilkan. Pukulan diarahkan dari atas ke bawah. Pukulan dapat diarahkan lurus dari atas atau melengkung (parabola). Secara umum, penyerpihan awal material bertujuan untuk menghilangkan kulit batuan. Kulit batuan yang lepas akan membentuk faset yang akan dijadikan acuan untuk melepas serpih selanjutnya.

Selanjutnya, penyerpihan bertujuan membentuk morfologi yang kemudian akan dijadikan acuan untuk membentuk serpih. Sasaran titik pukul sebisa mungkin tepat sejajar dengan faset yang diamati dari bidang datar materil. Semakin dekat titik pukul dari ujung faset semakin besar kemungkinan menghasikan serpih yang tipis, begitu pula sebaliknya. Serpih utuh dihasilkan minimal dengan 1-4 kali

${ }^{5}$ Getaran berlebihan biasanya menghasilkan serpih yang tidak utuh. panyerpihan. Penyerpihan pertama membentuk dataran pukul, yang menghasilkan 1 serpihan dengan 1 bidang datar pada batu inti (DP). Penyerpihan kedua dan ketiga membentuk faset yang menghasilkan 2 serpih dengan masingmasing 3 bidang pangkasan pada setiap serpih dan 3 bidang pangkasan pada batu inti - terdiri dari 1 bidang datar (DP), dan 2 bidang yang membentuk faset (calon punggungan serpih selanjutnya). Penyerpihan keempat yaitu melepaskan serpihan yang menghasilkan serpih dengan 4 bidang pangkasan dalam 4 kali penyerpihan ${ }^{6}$ - terdiri dari 1 bidang datar (DP), 2 bidang pada dorsal, dan 1 bidang pada bagian ventral.

Pada saat penyerpihan, hal yang paling penting adalah kemampuan mental mental template (Richard Leakey, 2003: 48). Kemampuan memikirkan bentuk artefak yang ingin dibuat dan cara menghasilkan rangkaian operasional penyerpihan - cukup membantu pada saat penyerpihan. Selain itu, faktor keterampilan penting untuk dimiliki karena sedikit kesalahan - kesalahan sasaran, kurang tekanan, salah arah, dan lain-lain - menentukan hasil akhir serpih yang dihasilkan. Faktor lain yang penting yaitu kondisi tubuh harus fit dan rileks serta konsentrasi pikiran untuk menghindari kesalahan pukulan. Kesalahan sasaran pukulan akan menghasilkan serpih di luar keinginan bentuk artefak yang dihasilkan yaitu keterampilan pembuat dalam menyerpih material.

Sebelum penyerpihan dilakukan, terlebih dahulu disediakan 6 material sebagai bahan baku yang akan diserpih. Selain material bahan baku, batu pukul juga disediakan untuk memperlancar jalannya proses eksperimen. Daftar material dan batu pukul yang disediakan tercantum dalam tabel 1 dan 2 .

${ }^{6}$ Ketentuan ini berlaku apabila proses penyerpihan berjalan lancar. 
Tabel 1. Daftar Material Bahan Baku Eksperimen

\begin{tabular}{cccccccc}
\hline \multirow{2}{*}{$\begin{array}{c}\text { No. } \\
\text { Label }\end{array}$} & $\begin{array}{c}\text { Panjang } \\
(\mathbf{c m})\end{array}$ & $\begin{array}{c}\text { Lebar } \\
(\mathbf{c m})\end{array}$ & $\begin{array}{c}\text { Tebal } \\
(\mathbf{c m})\end{array}$ & $\begin{array}{c}\text { Berat } \\
\mathbf{( g r a m})\end{array}$ & Kondisi & $\begin{array}{c}\text { Korteks } \\
\mathbf{( \% )}\end{array}$ & Warna \\
\hline M1 & 12,2 & 10,0 & 7,3 & 790 & Pecah & 25 & Cokelat \\
\hline M2 & 6,8 & 9,3 & 5,2 & 470 & Pecah & 75 & Reddish Black \\
\hline M3 & 14,4 & 12,4 & 10,3 & 2040 & Pecah & 60 & Reddish Black \\
\hline M4 & 16,8 & 9,1 & 5,6 & 900 & Utuh & 100 & Very Pale Brown \\
\hline M5 & 16,3 & 11,4 & 8,2 & 1760 & Utuh & 100 & $\begin{array}{c}\text { Light Yellowish } \\
\text { Brown }\end{array}$ \\
\hline M6 & 14,5 & 11,0 & 7,5 & 780 & Pecah & 70 & Greyish Brown \\
\hline
\end{tabular}

Sumber: Ansar Rasyid, Tahun 2011

Tabel 2. Daftar Batu Pukul Eksperimen

\begin{tabular}{ccccccc}
\hline \multirow{2}{*}{$\begin{array}{c}\text { No. } \\
\text { Label }\end{array}$} & \multirow{2}{*}{ Beanis } & Batuan & Bentuk & \multicolumn{4}{c}{ Ukuran } \\
\cline { 4 - 7 } & & Panjang & $\begin{array}{c}\text { Lebar } \\
\text { (cm) }\end{array}$ & $\begin{array}{c}\text { Tebal } \\
\text { (cm) }\end{array}$ & $\begin{array}{c}\text { Berat } \\
\text { (gram) }\end{array}$ \\
\hline BP 1 & Andesit & Segitiga & 8,3 & 5,7 & 4,5 & 310 \\
\hline BP 2 & Andesit & Lonjong & 6,6 & 4,1 & 3,6 & 190 \\
\hline BP 3 & Andesit & Trapesium & 6,8 & 4,7 & 4,3 & 200 \\
\hline BP 4 & Andesit & Segitiga & 8,1 & 5,6 & 4,4 & 630 \\
\hline BP 5 & Andesit & Lonjong & 10,0 & 7,3 & 5,8 & 570 \\
\hline BP 6 & Andesit & Trapesium & 7,7 & 7,4 & 6,1 & 450 \\
\hline BP 7 & Andesit & Trapesium & 7,7 & 6,0 & 4,3 & 230 \\
\hline BP 8 & Andesit & Bulat & 11,5 & 10,2 & 8,4 & 1400 \\
\hline BP 9 & Andesit & Lonjong Pipih & 7,6 & 6,0 & 3,6 & 260 \\
\hline BP 10 & Andesit & Lonjong Pipih & 10,4 & 6,5 & 4,4 & 490 \\
\hline
\end{tabular}

Sumber: Ansar Rasyid, Tahun 2011

\section{c. Eksperimen Material 1 (M1)}

Tahap awal penyerpihan Material 1 (M1), yaitu menentukan bidang yang akan dijadikan dataran pukul. Dataran pukul yang ideal, yaitu bidang datar di salah satu sisi material. Percobaan pada material 1 ini tidak dilakukan pembentukan bidang datar, karena salah satu bidang sudah membentuk bidang datar.

Dataran pukul yang dipilih disesuaikan dengan posisi dan kemiringan bidang yang ingin diserpih. Dataran pukul akan dialihkan ke bidang lain yang jika bidang sebelumnya tidak bisa menghasilkan serpihan yang utuh. -bidang pangkasan membentuk sudut lebih $90^{\circ}$ dari dataran pukul. Posisi dataran pukul dan arah penyerpihan juga menjadi perhatian pada eksperimen ini. Ada dua cara memposisikan dataran pukul yaitu dengan cara lurus (horizontal) dan miring (diagonal). Arah penyerpihan juga ada dua yaitu lurus dari atas dan melengkung (parabola).

Dataran pukul yang diposisikan horizontal digunakan untuk menghasilkan serpihan yang besar. Dataran pukul yang horizontal sering kali dikombinasikan dengan arah penyerpihan lurus namun kadang kala dengan arah penyerpihan melengkung (parabola). Sedangkan dataran pukul yang diposisikan miring (diagonal) tujuannya untuk meminimalisir kesalahan pukulan. Posisi dataran pukul diagonal biasanya dikombinasikan dengan arah pukulan yang melengkung (parabola).

Penyerpihan pada batu inti dihentikan karena ukuran batu inti yang kecil. Ukuran batu inti yang kecil sulit untuk 

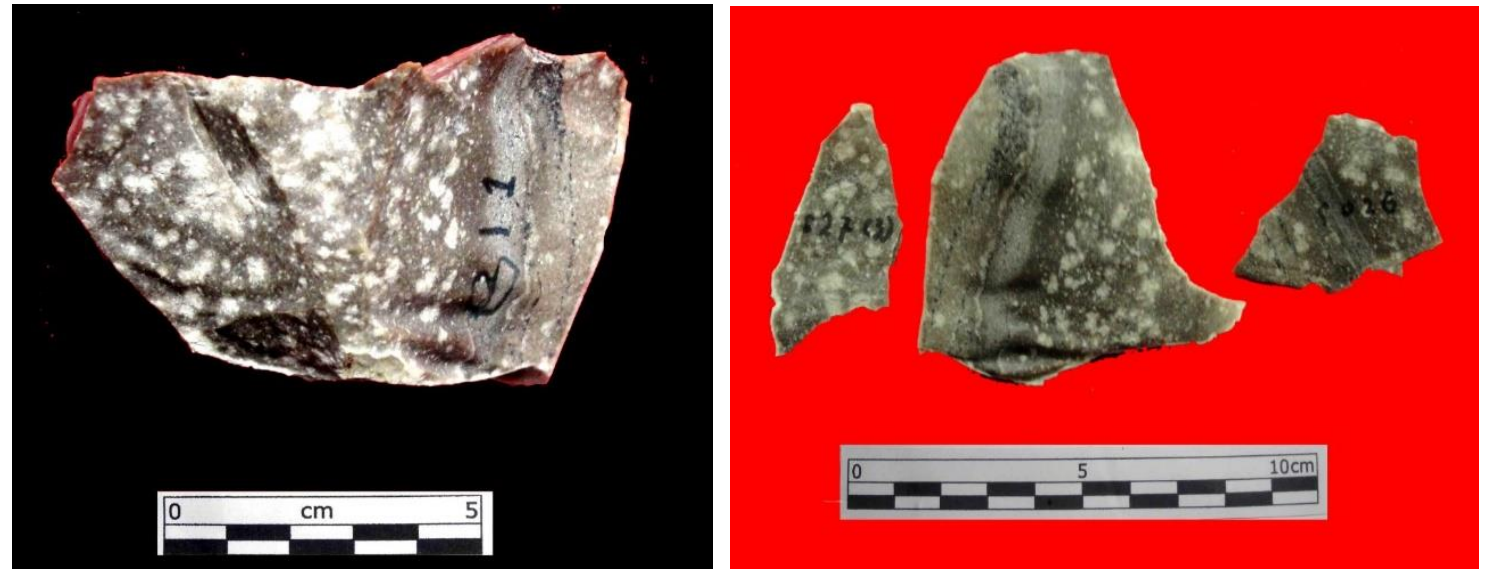

Gambar 1 dan 2. Batu inti material 1 (kiri) dan sampel serpih dari material 1

(Sumber: Ansar Rasyid, Tahun 2011)

dipegang sehingga menyulitkan dalam proses penyerpihan, dan menyebabkan bidang yang terbentuk menjadi sempit. Bidang yang sempit menyulitkan dalam menentukan sasaran pukulan, dan berakibat pada tingginya tingkat kesulitan untuk membentuk artefak yang diinginkan.

Pemangkasan pada material pertama hanya menggunakan dua batu pukul -BP 1 dan BP 3- dari empat macam batu pukul yang disediakan. Kedua batu pukul mengalami kerusakan pada salah satu sisinya. Kerusakan batu pukul terjadi akibat benturan langsung dengan batu inti. Bentuk kerusakan batu inti berupa goresan dan terjadi serpihan-serpihan kecil yang menginggalkan cacat. Tingkat kerusakan kedua batu pukul belum terlalu parah dan memungkinkan untuk digunakan pada penyerpihan selanjutnya.

\section{d. Eksperimen Material 2 (M2)}

Letak dataran pukul difokuskan pada satu bidang karena bidang datar cukup luas dan membentuk sudut kurang dari $90^{\circ}$ dari bidang yang ingin dipangkas. Posisi dataran pukul lebih sering diposisikan miring (horizontal). Perlakuan tersebut menandakan bahwa butuh penyerpihan yang singkat untuk menghasilkan serpih yang baik. Begitu juga dengan arah pukulan yang lebih sering menggunakan arah pukulan melengkung (parabola). Perlakuan ini- sesuai kemampuan dan si pembuatdilakukan untuk meminimalisir kesalahan pukulan yang akan menghasilkan serpih utuh.

Penyerpihan pada batu inti dihentikan karena ukuran batu inti yang kecil. Ukuran batu inti yang kecil tidak lagi memberi media pegangan yang baik sehingga menyulitkan dalam proses penyerpihan. Ukuran batu yang kecil, menyebabkan bidang yang terbentuk menjadi sempit. Bidang yang sempit menyulitkan dalam menentukan sasaran pukulan.

Batu pukul yang disiapkan pada penyerpihan material 2, yaitu batu pukul yang digunakan pada penyerpihan material 1 (BP 1 dan BP 3) ditambah dua batu pukul baru (BP 5). BP 1 dan BP 3 masih digunakan pada eksperimen material 2 kerena kondisi masih memungkinkan untuk digunakan. Kondisi terakhir batu pukul pada penyerpihan ini mengalami kerusakan pada kedua ujung sebagai akibat benturan langsung dengan batu inti. Bentuk kerusakan batu inti berupa goresan dan terjadi serpihan-serpihan kecil pada salah satu sisinya.

\section{e. Eksperimen Material 3 (M3)}

Material 3 (M3) merupakan material yang paling besar di antara material lain. Penyerpihan awal bertujuan untuk 
membelah material menjadi dua bagian, dengan harapan akan terbentuk bidang datar pada sisi yang pecah. Dibutuhkan batu pukul besar dan tenaga yang besar memecahkan material. Material dipukul tepat di tengahtengah material, tetapi cara ini tidak berhasil. Batu pukul yang digunakan untuk membelah material, yaitu batu pukul 4 (BP 4) dan batu pukul 8 (BP 8). BP 4 terbelah pada saat pukulan kelima dan BP 8 hanya mengalami sedikit kerusakan (aus).

Cara kedua yang ditempuh yaitu penyerpihan langsung di salah satu bidang datar. Cara seperti ini ditempuh karena untuk memecahkan material menjadi dua bagian gagal. Pertama-tama akan dibentuk fasetfaset baru pada batu inti yang lebih teratur dengan melepas beberapa serpih. Faset yang terbentuk kemudian akan dijadikan panduan untuk penyerpihan selajutnya.

Letak dataran pukul tidak konsisten pada satu bidang, tetapi akan dialihkan ke bidang lain jika terjadi perubahan morfologi batu inti. Perubahan yang dimaksud adalah morfologi batu inti yang terbentuk tidak memungkinkan menghasilkan serpih, atau antara DP dan bidang pangkasan membentuk sudut lebih dari $90^{\circ}$. Bidang datar yang menyempit pada batu inti menjadi salah satu alasan pemindahan bidang batar.

Penyerpihan batu inti dihentikan karena kualitas batu inti kurang baik. Tekstur batu inti yang tersisa pecah-pecah atau retak-retak dan rapuh. Kualitas batu inti yang kurang baik tidak dapat menghasilkan serpih yang baik. Batu inti yang retak-retak mengikuti pola kemungkinan besar menghasilkan serpih yang retak atau bahkan pecah.

Batu pukul yang disiapkan yaitu batu pukul yang digunakan pada penyerpihan material 1 (BP 1 dan BP 5). BP 5 dan BP 1 adalah batu pukul yang digunakan pada penyerpihan 2 material yang sebelumnya. Kedua batu pukul tersebut masih digunakan karena kualitasnya masih bagus. Kondisi terakhir batu pukul pada panyerpihan ini mengalami kerusakan pada kedua ujung sebagai akibat benturan langsung pada batu inti. Bentuk kerusakan batu inti berupa goresan, gumpil, pecah (terbelah), dan terjadi serpihan-serpihan kecil pada salah satu sisinya.

\section{f. $\quad$ Eksperimen Material 4 (M4)}

Material 4 (M4) berbentuk lonjong dan ditutupi oleh kulit batuan di semua sisinya. Material ini membutuhkan teknik khusus pada awal penyerpihannya. Rencana awal penyerpihan adalah menghasilkan serpihan besar untuk serpihan pertama. Serpihan besar akan menghasilkan satu bidang yang luas. Bidang yang luas akan dijadikan sasaran titik pukul sekaligus dataran pukul.

Setelah menghasikan beberapa serpih, terbentuk dua bidang datar pada batu inti. Bidang datar yang terbentuk terletak di kedua sisi batu inti. Bidang datar dimanfaatkan sebagai sasaran titik pukul.

Dataran pukul akan dialihkan ke sisi yang lain jika morfologi batu inti yang terbentuk di sekitar dataran pukul tidak dapat menghasilkan serpih. Dataran pukul yang dipilih adalah dataran pukul di sisi lain yang berlawanan dari dataran pukul sebelumnya. Dataran pukul yang selalu dialihkan ke bidang yang lain menghasilkan arah pangkasan yang berlawanan, sebagai akibat dari arah pangkasan dari dua bidang datar yang berlawanan pula.

Penyerpihan pada batu inti dihentikan karena ukuran batu inti yang kecil. Ukuran batu inti yang kecil tidak baik lagi untuk digenggam sehingga menyulitkan dalam proses penyerpihan. Ukuran batu inti yang kecil, juga menyebabkan bidang yang terbentuk menjadi sempit. Bidang yang sempit menyulitkan dalam menentukan sasaran pukulan.

Batu pukul yang digunakan untuk menyerpih material 4, yaitu batu pukul 1, 2, 5 dan 9. Kerusakan batu pukul terjadi pada kedua ujung sebagai akibat benturan langsung pada batu inti. Bentuk kerusakan 
batu inti berupa goresan, gumpil dan terjadi serpihan-serpihan kecil pada salah satu sisinya.

\section{g. Eksperimen Material 5 (M5)}

Bentuknya yang lonjong dengan tepian membulat menyulitkan si pembuat mencari titik tepat untuk melepas serpihan pertama. Dibutuhkan batu pukul besar untuk melepas serpihan dari batu inti. Batu pukul besar, pukulan keras dan sasaran tepat di tengah-tengah batuan mengakibatkan material terbelah dua dan menghasilkan dua buah pecahan yang dapat digunakan sebagai batu inti.

Kedua pecahan material cocok digunakan sebagai batu inti karena salah satu bagian dari masing-masing pecahan menghasilkan bidang datar yang luas dan akan dijadikan bidang datar untuk memilih titik pukul, meliputi: pertama, Batu Inti 5.1. Batu inti 5 berukuran panjang $12 \mathrm{~cm}$, lebar $8,3 \mathrm{~cm}$, tebal $6,4 \mathrm{~cm}$ dan, berat 760 gram. Bidang yang ditutupi kulit pada batu inti sebelum penyerpihan sekitar $65 \%$, yang tidak tertutupi kulit, yaitu bidang datar bekas pecahan material 5. Letak dataran pukul pada batu inti difokuskan pada satu bidang dan tidak dipindahkan ke bidang yang lain. Langkah ini ditempuh karena bidang datar yang tersedia cukup luas, sehingga si pembuat memiliki banyak pilihan penempatan titik pukul. Serpih yang ingin dihasilkan yaitu serpih yang memanjang, untuk itu dibentuk faset dari satu arah yang kemungkinkan menghasilkan serpih panjang.

Kedua, Batu Inti 5.2 adalah pecahan kedua dari material 5, ukurannya lebih panjang dari batu inti 5.1, ukuran panjang 16 , lebar $9,5 \mathrm{~cm}$, tebal $6,7 \mathrm{~cm}$ dan, berat 1000 gram. Bidang yang ditutupi kulit batuan sekitar $75 \%$. Batu pukul yang digunakan pada penyerpihan kali ini masih menggunakan batu pukul pada penyerpihan sebelumnya yaitu batu pukul 9 yang berukuran panjang 7,6 cm, lebar $6 \mathrm{~cm}$, tebal $3,6 \mathrm{~cm}$ dan berat 260 gram.
Letak dataran pukul pada batu inti difokuskan di satu bidang dan tidak berpindah ke bidang yang lain, hal ini dikarenakan bidang datar yang cukup luas. Bidang datar yang luas memunginkan si pembuat memiliki banyak pilihan penempatan titik pukul.

Penyerpihan pada kedua batu inti dihentikan karena ukuran batu inti yang kecil. Ukuran batu inti yang kecil sulit untuk dipegang sehingga menyulitkan dalam proses penyerpihan selanjutnya. Ukuran batu yang kecil, manyebabkan bidang yang terbentuk menjadi sempit. Bidang yang sempit menyulitkan dalam menentukan sasaran pukulan.

Batu pukul yang digunakan pada penyerpihan batu inti 5.1 dan batu inti 5.2, yaitu batu pukul 9 (BP 9). Kerusakan batu pukul terjadi pada kedua ujung sebagai akibat benturan langsung pada batu inti. Bentuk kerusakan batu inti berupa goresan, gumpil dan terjadi serpihan-serpihan kecil pada salah satu sisinya.

\section{h. Eksperimen Material 6 (M6)}

Hampir semua bagian material memiliki bidang datar yang memungkinkan dijadikan dataran pukul. Penyerpihan dilakukan di satu sisi bidang datar yang membentuk faset. Bidang datar yang dipilih adalah bidang datar dengan kemiringan kurang dari $90^{\circ}$ dari bidang yang lain. Teknik yang digunakan adalah penyerpihan dengan serpihan satu arah dan diharapkan dapat menghasilkan serpih yang memanjang.

Akibat batu yang tersisa sudah berkuran kecil, sehingga tidak memungkinkan lagi untuk dilakukan penyerpihan. Batu inti berukuran kecil susah diserpih karena tidak ada lagi bagian yang dijadikan landasan genggaman dan menyulitkan dalam proses menentukan dataran pukul, karena dataran pukul yang tersisa sudah menyempit.

Batu pukul yang digunakan pada penyerpihanbatu inti 6 adalah batu pukul 10 
(BP 10). Kerusakan batu pukul terjadi pada kedua ujung sebagai akibat benturan langsung pada batu inti. Bentuk kerusakan batu inti berupa goresan dan terjadi serpihan-serpihan kecil pada salah satu sisinya.

\section{Hubungan Serpih dengan Teknik Penyerpihan}

\section{a. Jenis Serpih}

Teknik pemangkasan langsung dengan pemilihan dataran pukul secara acak menghasilkan 185 serpih. $68 \%$ di antaranya serpih utuh, $15 \%$ chips, $9 \%$ fragmen serpih proksimal, $6 \%$ fragmen serpih split, dan $2 \%$ fragmen serpih distal. Teknik penyerpihan langsung dengan pemilihan dataran pukul pada satu bidang menghasilkan 206 serpih. $50 \%$ serpih utuh, $11 \%$ chips, $12 \%$ fragmen serpih proksimal, $4 \%$ fragmen serpih split, $8 \%$ fragmen serpih medial, dan $15 \%$ frgamen serpih distal.

Data jenis serpih di atas dapat dijelaskan bahwa, teknik penyerpihan langsung dengan pemilihan dataran pukul secara acak memungkinkan untuk memperoleh serpih utuh lebih besar dibandingkan dengan pemilihan dataran pukul pada satu bidang. Serpih utuh yang dihasilkan berbanding terbalik dengan fragmen serpih -proksimal, medial dan distal $^{7}$ - yang dihasilkan. Pilihan dataran pukul secara acak menghasilkan fragmen serpih lebih sedikit dibandingkan dengan pemilihan dataran pukul pada satu bidang. Perolehan tersebut disebabkan karena pada dataran pukul acak, pembuat bebas memilih bidang yang ingin di serpih sesuai dengan keinginan pada morfologi yang terbentuk di batu inti, sehingga si pembuat memiliki peluang besar untuk menghasilkan serpih utuh.

Si pembuat tidak memiliki banyak pilihan terhadap batu inti untuk penyerpihan

${ }^{7}$ Kecuili pragmen serpih split dan chip. Split terjadi bukan karena pemilihan dataran pukul, akan tetapi teradi karena kesalahan sasaran pukulan (titik pukul) pada saat batu pukul yang dilakukan pada satu bidang datar. Si pembuat hanya fokus pada satu bidang datar. Jika morfologi yang terbentuk tidak memungkinkan untuk menghasilkan serpih utuh, dibentuk morfologi baru dengan penyerpihan pada bidang yang lain. Pembentukan morfologi inilah yang menghasikan serpih tidak utuh.

\section{b. Morfologi Bentuk Serpih}

Teknik penyerpihan langsung dengan pemilihan dataran pukul acak menghasilkan 185 serpih yang memiliki 5 morfologi bentuk. Bentuk tersebut diantaranya: Segi Tiga $57 \%$, Trapezium $26 \%$, Jajaran Genjang 14\%, Pipih 2\% dan Segi Panjang $1 \%$.

Penyerpihan pada satu bidang datar menghasikan 5 morfologi bentuk dari 206 serpihan. Bentuk tersebut, diantaranya: $56 \%$ Segi Tiga, Trapezium 36\%, Jajaran Genjang $3 \%$, Segi Panjang 3\%, dan Pipih 2\%.

Berdasarkan data di atas dapat disimpulkan bahwa kedua teknik penentuan dataran pukul sama-sama menghasilkan morfologi bentuk yang sama -Segi Tiga, Trapezium, Jajaran Genjang, Segi Panjang dan Pipih- dengan persentase tidak jauh berbeda.

\section{Analisis Material, Batu Inti dan Jumlah Serpih}

Proses pengambilan bahan material yang telah dilakukan, terdapat 6 material yang dipilih secara acak. Perbandingan ukuran panjang, lebar, dan tebal material menunjukkan bahwa material yang paling panjang, yaitu: Material 4. Material yang paling panjang berikutnya, terdiri: Material 5, Material 6, Material 3, Material 1. Material terkecil, yaitu Material 2. Material yang paling lebar, yaitu Material 3. Material yang paling lebar berikutnya, terdiri: Material 5, Material 6, Material 4, Material 1. Material terkecil, yaitu Material 2.

berbenturan dengan batu inti. Sedangkan chip terbentuk karena adanya serpihan-serpihan kecil pada saat panyarpihan. 
Material yang paling tebal, yaitu Material 3. Material yang paling tebal berkutnya, terdiri: Material 3, Material 5, Material 6, Material 1, Material 4. Material terkecil, yaitu Material 2. Perbandingan berat masingmasing material.

Pada Material 3 adalah material yang paling berat, yakni 2040 gram. Material yang paling berat berikutnya, terdiri: Material 5, dengan ukuran 1760 gram dan Material 4 memiliki berat 900 gram, sedangkan Material 1 adalah 790 gram dan Material 6 adalah 780 gram. Material 2 yang paling ringan dari material lainnya, beratnya sekitar 470 gram.

Berdasarkan data eksperimen yang dilakukan terhadap 6 material, jumlah keseluruhan serpih yang dihasilkan sebanyak 391 batu. Persentase jumlah serpihan dari 6 material.

Material 5 merupakan material yang paling banyak menghasilkan serpih dengan jumlah sepihan 110 serpih. Jumlah persentasenya 28\%. Material 5 menghasilkan banyak serpih karena terdiri dari dua buah batu inti. Material berikutnya yang paling banyak menghasilkan serpih, yaitu Material 3. Jumlahnya 82 serpihan dengan persentase $21 \%$. Material 06 menghasilkan 70 serpih dengan jumlah persentase $18 \%$. Material 1 dan Material 4 memiliki persentase yang sama yaitu 13\%, jumlah serpihan yang dihasilkan Material 1, yaitu 53 serpih sedangkan Material 4 sebanyak 50 serpih. Material 2 adalah material yang paling sedikit menghasilkan jumlah sepihan, yaitu 26 serpih dengan persentase $7 \%$. Perbandingan volume berat untuk masing-masing batu inti.

Pada batu inti 03 dari Material 3, adalah batu inti yang memiliki volume paling berat dengan ukuran 400 gram. Batu inti 06 adalah batu inti yang memiliki volume paling berat setelah batu inti 03 . Batu inti yang dihasilkan dari material 06 memiliki berat 350 gram. Berikutnya, yaitu 2 batu inti yang berasal dari 1 material, yaitu batu inti 05. 1 dan batu inti 05. 2, dari
Material 5. Kedua batu inti tersebut jika di jumlahkan maka volume berat secara keseluruhan, yaitu 250 gram. Batu inti 01 dan batu inti 02 hampir memliki volume berat sama. Batu inti 01 memiliki berat 200 gram sedangkan batu inti 02 memiliki berat 190 gram, dan batu Inti yang paling ringan, yaitu batu inti 04 , dengan berat 140 gram.

Data di atas memperlihatkan bahwa volume berat dan ukuran material berkorelasi kuat dengan jumlah serpih yang dihasilkan. Terlihat pada jumlah serpih yang dihasilkan. Semakin tinggi volume berat dan ukuran suatu material maka semakin banyak serpih yang dapat dihasilkan. Sebaliknya, semakin rendah volume berat material maka semakin sedikit juga jumlah serpih yang dihasilkan. Contoh perbandingannya: Material 5 dan Material 03 yang memiliki volume berat paling tinggi. Material 5 yang menghasilkan 28\% serpih juga menghasilkan 2 batu inti memiliki volume berat yang tinggi, yaitu 1760 gram. Material 3 yang menghasilkan $21 \%$ serpih juga memiliki volume berat yang tinggi yaitu 2040 gram. Material paling sedikit menghasilkan serpih, yaitu material 02 yang volume berat materialnya juga paling rendah di antara semua material lainnya. Material 2 yang menghasilkan 7\% serpih memiliki volume berat 470 gram.

Ukuran dan berat batu inti tidak memiliki korelasi kuat dengan jumlah serpih yang dihasilkan. Dicontohkan pada batu inti 05 dari Material 5 -yang menghasilkan serpih paling banyak- mengahasilkan volume batu inti yang lebih ringan dibandingkan batu inti 6 dari Material 6 yang menghasilkan serpih lebih sedikit dari Material 5. Sebaliknya, Material 2 -yang menghasilkan serpih paling sedikit menghasilkan volume batu inti yang lebih besar dibanding batu inti 04 dari Material 4 -yang menghasilkan serpih lebih banyak dari Material 2. 


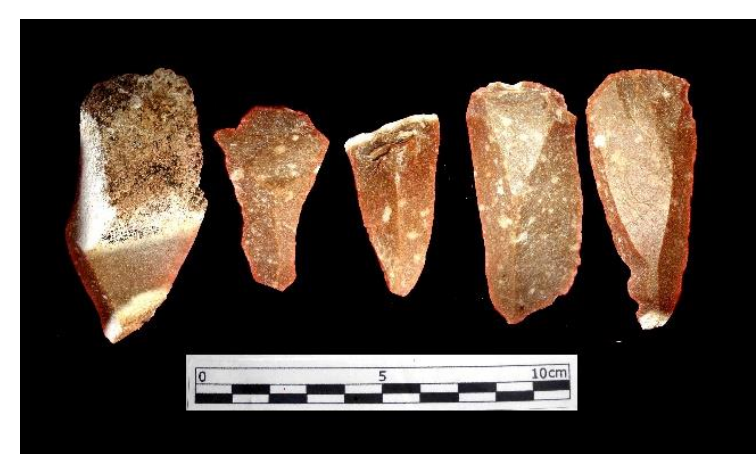

Gambar 7: Bentuk serpih memanjang

(Sumber: Ansar Rasyid, Tahun 2011)

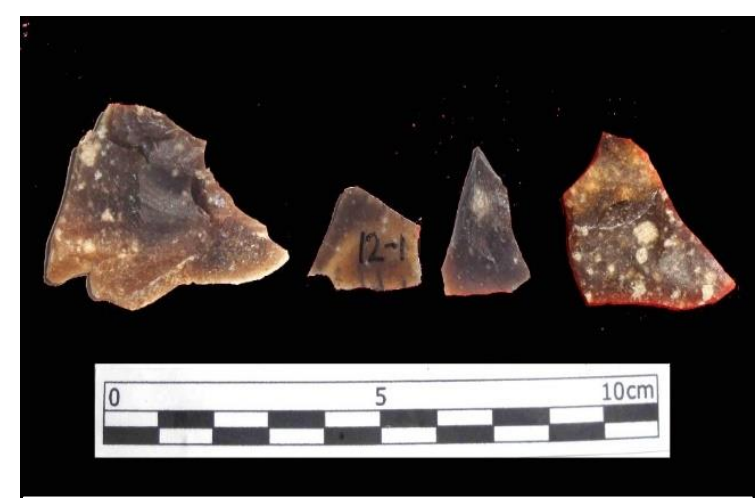

Gambar 8: Bentuk serpih biasa

(Sumber: Ansar Rasyid, Tahun 2011)

\section{Hubungan Atribut Serpih dengan penyerpihan}

Atribut yang terdapat pada serpih, baik teknik pemilihan dataran pukul secara acak maupun dataran pukul pada satu bidang datar menghasilkan atribut serpih yang sama. Umumnya, semua serpih menghasilkan atribut utama teknologi pembuatan. Perbedaan terlihat pada arah pangkasan serpih. Teknik pemilihan dataran pukul secara acak memperlihatkan arah bidang pangkasan yang acak juga, sedangkan teknik pemilihan dataran pukul pada satu bidang datar memiliki arah bidang pangkasan yang searah dengan bidang pangkasan yang lainnya.

Perbedaan arah pangkasan banyak terjadi pada serpih yang dibuat dengan teknik pemilihan dataran pukul secara acak. Perbedaan terjadi karena posisi dataran pukul selalu dipindahkan ke bidang lain sesuai dengan morfologi yang terbentuk. Orientasi arah pangkasan juga mengikuti pola morfologi batu inti. Berbeda dengan teknik pemilihan dataran pukul pada satu bidang datar. Teknik pangkasan selalu searah dengan bidang pangkasan yang lain karena, penyerpihan selalu dilakukan pada satu bidang datar. Arah pangkasan pada bidang pangkasan juga selalu sama dengan arah dan bidang pangkasan yang lain.

\section{Hubungan Bentuk Serpih dengan Teknik Penyerpihan}

Bentuk serpih yang dihasilkan memperlihatkan perbedaan yang signifikan. Teknik pemilihan dataran pukul secara acak cenderung lebih banyak menghasilkan bentuk serpih biasa dibandingkan bentuk memanjang. Terlihat dari tiga material $-\mathrm{M} 1$, M3 dan M4- yang diserpih secara acak ratarata menghasilkan $60 \%$ serpih biasa dan $40 \%$ serpih memanjang. Teknik pemilihan dataran pukul pada satu bidang cenderung menghasilkan serpih biasa lebih sedikit dibandingkan serpih berbentuk memanjang. Terlihat dari tiga material -M2 dan M5 yang diserpih menghasilkan serpih bentuk memanjang rata-rata lebih dari $60 \%$ kecuali pada material 6 yang menghasilkan serpih biasa $53 \%$ dan bilah $47 \%$.

\section{PENUTUP}

Teknik pemilihan dataran pukul yang mudah menghasilkan serpih adalah teknik pemilihan dataran pukul secara acak. Teknik ini dianggap mudah menghasilkan serpihan karena mudah diterapkan tanpa aturanaturan atau ketentuan tertentu. Misalnya dalam hal pemilihan dataran pukul yang bisa dipilih dari bidang yang berbeda dalam satu material. Dataran pukul yang berbeda menyebabkan arah pangkasan berbeda orientasi (tidak teratur), perbedaaan tersebut dapat diamati pada serpih dan batu inti yang dihasilkan. Berbeda halnya dengan teknik pemilihan dataran pukul pada satu bidang datar. Dataran pukul yang hanya pada satu bidang datar pada satu material menyebabkan kurangnya pilihan dalam hal memilih bidang yang ingin dipangkas. 
Kurangnya pilihan dataran pukul memaksa pembuat mempersiapkan perencanaan yang matang sebelum masuk pada proses penyerpihan. Dataran pukul pada satu bidang juga berimplikasi pada arah pangkasan yang selalu mengarah pada satu arah, hal ini dapat diamati pada serpih dan batu inti yang dihasilkan.

Bentuk serpih yang dihasilkan, penerapan teknik pemilihan dataran pukul secara acak lebih efektif untuk menghasilkan serpih dengan bentuk yang biasa (serpih pendek) sedangkan teknik pemilihan dataran pukul pada satu bidang datar lebih efisien dalam menghasilkan serpih yang berbentuk memanjang. Bentuk memanjang mudah dihasilkan karena arah pemangkasan yang selalu sejajar dengan arah pemangkasan, sehingga serpih yang dihasilkan cenderung memanjang. Meskipun demikian, tidak jarang teknik ini menghasikan serpih yang pendek atau rusak karena sedikit kesalahan akan menghasilkan serpih yang patah menjadi beberapa bagian.
Kemampuan memikirkan bentuk dan cara menghasilkan artefak yang ingin dibuat cukup membantu pada saat penyerpihan. Selain itu, faktor keterampilan penting untuk dimiliki karena sedikit kesalahan -kesalahan sasaran, kurang tekanan, salah arah, dan lain-lain- menentukan hasil akhir serpih yang dihasilkan. Hal lain yang menentukan pula adalah kondisi tubuh harus fit dan rileks serta konsentrasi pikiran untuk menghindari kesalahan pukulan. Kesalahan sasaran pukulan akan menghasilkan serpih diluar keinginan bentuk artefak yang dihasilkan yaitu keterampilan pembuat dalam menyerpih material.

\section{UCAPAN TERIMA KASIH}

Terima kasih saya ucapkan kepada segenap pengajar Jurusan Arkeologi Universitas Hasanuddin karena telah membimbing saya. Teman-teman saya angkatan 2005 Arkeologi Universitas Hasanuddin, terima kasih saya ucapkan karena telah membantu dalam menyelesaikan tulisan ini.

\section{DAFTAR PUSTAKA}

Andari, C., 1995. Teknik Lukisan Cap Tangan pada Gua-Gua di Belae Pangkep (skripsi). Ujung Pandang: Jurusan Sejarah dan Arkeologi Unhas.

Anonim, 1999. Metode Penelitian Arkeologi Arkeologi. Departemen Pendidikan nasional. Pusat Penelitian Arkeologi Nasional. Jakarta.

Anonim, 2001. Penelitian Arkeologi Prasejarah di Situs Wessae (Ralla), Kecamatan Taneteriaja, Kabupaten Barru, Propinsi Sulawesi Selatan. Laporan Penelitian. Makassar: Balai Arkeologi Makassar.

Anonim, 2003. Karakter Situs Wessae berdasarkan Temuan Perkakas Batu. Laporan Penelitian. Makassar: Balai Arkeologi Makassar. 
Arifin, Fauzi., 2013. Identifikasi Mikrofosil Foraminifera untuk menentukan Paleobatimetri Batugamping Formasi Tonasa, Daerah Ralla, Kecamatan Tanete Riaja, Kabupaten Barru, Propinsi Sulawesi Selatan. Prosiding Hasil Penelitian Fakultas Teknik Volume 7 Desember 2013. Makassar: Universitas Hasanuddin. Diakses tanggal 10 Oktober 2017. http://download.portalgaruda.org/article.php

Coles, J., 1979. Experimental Archaeology. London: Academic Press.

Forester, H., 2007. Ribuan Gunung Ribuan Alat Batu. Jakarta: Kepustakaan Populer Gramedia.

Howell, F, Clark., 1977. Manusia Purba. Jakarta: Tira Pustaka.

Idrus, 1996., Analisis Teknologi terhadap Artefak Batu Situs Pacciro, Kecamatan Taneteriaja, Kabupaten Barru, Propinsi Sulawesi Selatan. Skripsi. Ujung Pandang: Universitas Hasanuddin.

Leakey, Richard, 2003. Asal-usul manusia. Jakarta: KPG (Kepustakaan Populer Gramedia).

Outram A. K., 2008. "Experimental Archaeology”. World Archaeology, 40 no. 1: 1-6. Roudledge. London.

Soejono, R. P., 1993. Sejarah Nasional Indonesia I (edisi revisi). Jakarta: Balai Pustaka.

Utomo, Danang Wahyu, 2003. Alat Batu Bergerigi dari Situs Wessae, Barru, Sulawesi Selatan. Walennae. Makassar: Balai Arkeologi Makassar

Whitteker, J, C., 2004. American Flintknappers-Stone Age Art in the Age of Computers: University of Texas Press. 

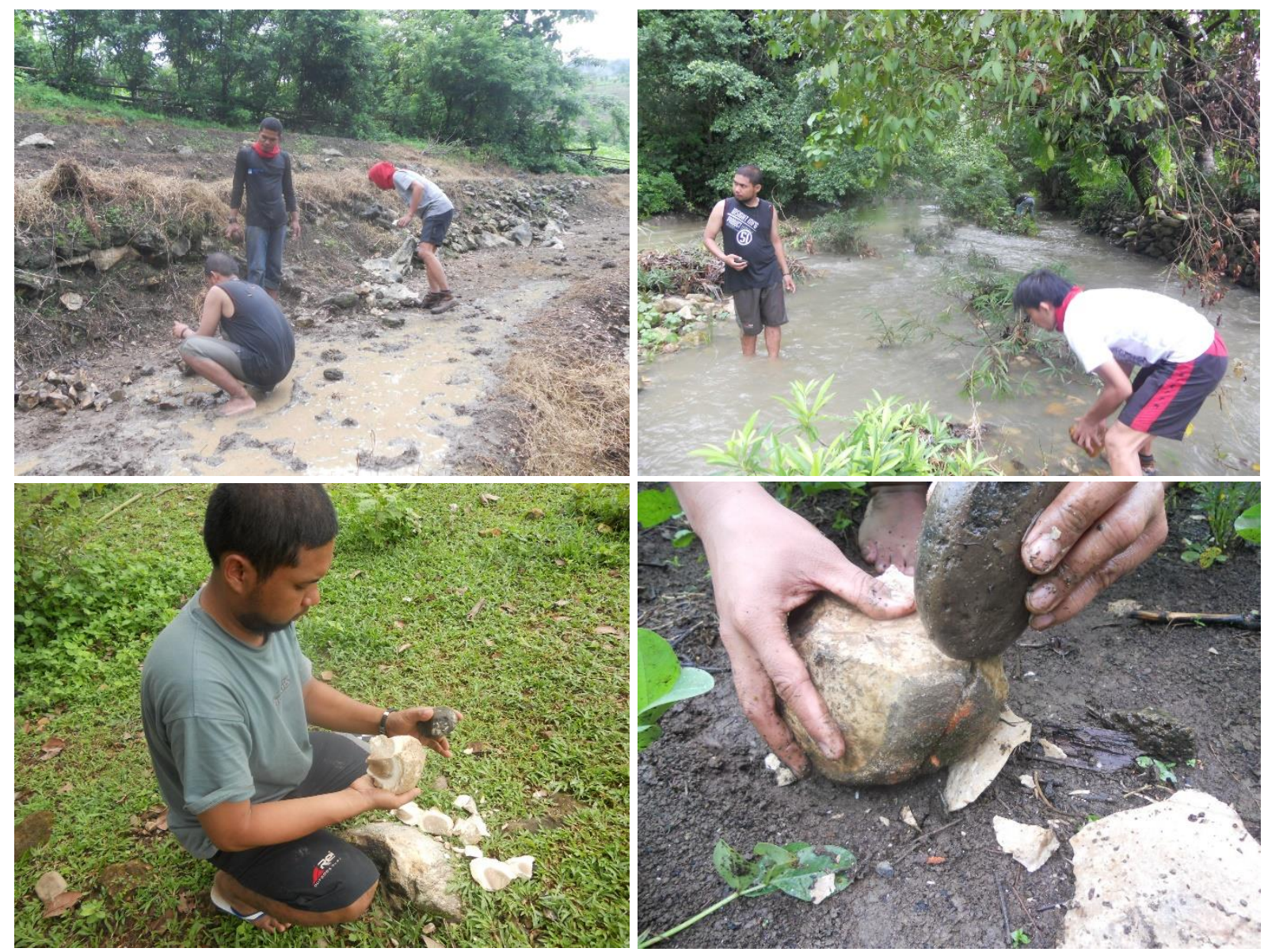

Lampiran Foto kegiatan survei lokasi pengambilan bahan material chert dan latihan eksperimen

(Sumber: Dok. Ansar Rasyid, Tahun 2011) 